\title{
What determine the givers behavior? The mindset of Waqf giver in Malaysia
}

\begin{abstract}
There are several questions that have fascinated behavioral scientists for decades; one of them was: why do we give things like money, effort, guidance, help \& kind words or/ and time to others? Researchers have looked into why people donate, why they don't do it as much as they would hope to and how to bridge this gap. But no clear answer to the psychology of giving; the inner motive that drive us to give. Available literature shows that charitable giving arises from a complexity of motives, attitudes, and demographic attributes. Some may give out of altruism, while others give out of egoism. Others find mercy, humility, obligation, tax deductions, and access to elite business and social networks as motives for giving. However, what the real motivations in the highest giving individuals is not very clear, specially what is related to Waqf in Malaysia. Waqf is a financial charitable endowment established by withholding immovable and movable properties to perpetually spend its revenue on fulfilling public needs; it has been the main source for public services that been provided to communities. The purpose of this paper is to explore traits of givers, in order to present factors associated with giving behavior. A qualitative method was used to attain the study objectives. The findings signified that unique thinking and psychology behind helping others played a crucial role in donor contribution to Waqf; this concludes that sincerity determinant quality of givers.
\end{abstract}

Keywords: Waqf, Giving Behaviors, Mindsets of giver
Volume 4 Issue I - 2020

\author{
Shadiya Mohamed S Baqutayan \\ Perdana Center for Science Technology and Innovation (STI) \\ Policy Studies, University Technology Malaysia (UTM), Malaysia \\ Correspondence: Shadiya Mohamed S Baqutayan, Universiti \\ Teknologi Malaysia, Perdana School of Science, Technology and \\ Innovation Policy, Malaysia, Tel 006019346335I, 0321805340; \\ Email Shadiya.k@utm.my
}

Received: February 19, 2019 | Published: January 23, 2020

\section{Introduction}

Researcher explores different perspectives of models, theories, and the psychological paradigms to explain why people give and what motivate them to participate in Waqf giving behavior. Before we proceed further, let us explain what is the meaning of Waqf? Waqf is a financial charitable endowment established by withholding immovable and movable properties to perpetually spend its revenue on fulfilling public needs, once the property is created as Waqf, it could never be given as gift, inherited, or sold. Traditionally, Waqf was inculcated in Muslims' culture, and has included in all walks of life. When it was the main source for various public services that been provided to communities.

Most of scholars find that donation and charitable behaviors are motivated by a blend of altruism and self-interest motives, ${ }^{1}$ personal faith, sense of moral obligation, and feeling of achievement of making a difference, ${ }^{2}$ personal connection and values, personal recognition, happiness, supporting family and friends, public benefit, and generation of new donors. ${ }^{3}$ Giving charity is essential to the spiritual life, reflecting as they do an awareness of the interconnectedness of all beings. It is a quality that testifies to the depth of one's humanity and one's capacity for self-transcendence. It overpowers the class structures that are in place and provides true equality for all in society. Giving at its essence is the creative activity of the heart. The richest of all people are those who share themselves, for a person's true wealth is measured by their ability to share. All loves the charitable individual and their friendship is prized highly. They gain more spiritual strength by bestowing kindness and generosity to others. They gain more beauty, purity, and truth in their lives and acquire great treasures of the spirit. Charity instills sympathy, consideration, and understanding. It ennobles the human spirit and expands the heart and is very helpful to spiritual progression and its evolution of higher consciousness.

\section{Literature review}

Giving charity is an act of benevolent good will toward all living beings, including self. Benevolent charity is an optimism that applied to the other person, which could be at many levels. Sometimes bearing the burden of another is a profound spiritual practice, which elevates one to think generously, speak generously, and act generously. It means that one is practicing relating to others as though they are part of one's family. Thinking well of others and speaking well of others is the basis for charitable giving. Each act of generous charity works to pry open the heart a little, like clearing a blocked stream one pebble at a time. The flow of spontaneity in acts of charity to one's family and community is then freed to follow.

Researchers have traditionally capitalized on motivations for giving, with a recently emerging focus on highlighting the mood benefits of giving; the emotional feelings of empowerment, joy, and inspiration that giving engenders. In recent years, however, more researchers have begun to consider a broader range of drives that influence on giving behavior "the motivations for giving". ${ }^{4}$ Some have considered trust and commitment as motivational factors to give, ${ }^{5}$ whereas other talked about social relations as a drive to give. ${ }^{6}$

With respect to motivation, a person develops an intention to change, based on self-beliefs; certainly, attitude, subjective norms and perceived behavior control ${ }^{7}$ personal values, ${ }^{8}$ altruism ${ }^{9}$ and past history. ${ }^{10}$ Although, several factors influence the givers attitudes toward donation, the decisions to donate are informed by both emotional and rational processes. ${ }^{11}$ Under these circumstances, our emotion and mental skill set relies on norms, past experience and personal values to direct the motivational force to useful and acceptable goals. ${ }^{12}$ In other words, attitude, subjective norms, perceived behavior control, personal values, altruism, and past history might help to translate 
the behavioral intention into donation or/and giving behavior (eg. participating in waqf).

Giving comes from the loving heart of a person who is willing to share abundantly all that is given to them. Expressing this quality of love becomes an action they perform by translating their spiritual energy and intention into physical giving. The generous act of charity enacts the quality of a willingness to share and to let go in order that one can follow their spiritual path. Paying attention to the needs of others is a generous act of charity, which is one of the most accessible ways to do that.

\section{Research methodology}

The purpose of this study is to describe the givers behavior from educationist, donors, Chairman of Awqaf Holdings, researchers, and trustees perspectives. The research seeks to uncover the characteristic of those who always participate in giving without looking for any tangible returns. In essence this study aims to also signify whether religion and culture play a role in influencing the givers behavior in Malaysia.

This study used qualitative methods as it seeks to understand human behavior and reasons that govern such behavior, ${ }^{13}$ to collect data that reflects the subjective experience of those donors who always participate in giving without looking back into what they give, why, and what they will get. A non-probability sampling method was used in this study, and a convenient sample of 8 participants was obtained. In sum, it is worth examining the psychology of givers, behavior and characteristics of a population that has been overlooked in much of the research literature on waqf, sadagh, and zakat. Therefore, this study on the mindset of waqf giver framework, with the hope of gaining knowledge about their characteristics that can contribute to the actualization of human ability, both men and women, on elevation of poverty and improving the quality of Muslims' life.

Data were gathered through open-ended qualitative interviews with eight-participants. The respondents were identified through purposive sampling. The data collection protocols were prepared by drafting interview questions, which provided the platform for data collection and analysis. The list of interview questions was given to two peer reviewers for feedback and revision. Towards that, we created an interview template using the specific questions to be asked during the interviews. The one-on-one interview protocol included questions that focused on the Amana given to the man as a responsible khalifa, Humble/Humility (Tawadhuk) characters, considerate/civility elements, and Altruisms.

The participants were eight from different backgrounds of educationist, donors, researchers, and trustees who were knowledgeable in their field, participate in giving, and manage waqf in Malaysia. Three interviewees were lecturers from public universities; another three interviewees were donors who always participate in giving, and two were trustees while the other was policymaker, indeed, all eight of them were Malay Muslims. The selected Malay participants were personally contacted and invited to participate in this study. Upon confirmation of their participation the interview schedule together with a study brief and consent form were emailed to them. The interviews were then scheduled on a date and time at a venue convenient to them. It was emphasized that the data collected during the interviews were private and confidential and that the anonymity of the respondents were maintained. All the interviews were recorded with permission from the respondents. The interviews were transcribed verbatim and then saved in electronic files and were later transferred to hard copy in order to assist data analysis. The data was coded to assist in identifying distinct and common themes through constant comparative analysis as specified by Yin (1994). Subsequently, based on the findings, the researchers were able to explain the particular giver behaviors of Muslim in Malaysia.

\section{Findings \& recommendations}

The findings covered characteristics of giver behaviors; a factor pushes them to give; their mindset; and the psychology behind giving behavior. Respondents appeared to be supportive and passionate about the subject matter. These interview sessions were regarded as achieving this research objective and introducing psychology framework that is considered the first in Waqf researches.

It has been suggested that personal values can also partially explain donor behavior. ${ }^{14}$ Personal values have been defined as "organized sets of preferential standards used in making selections of objects and actions, resolving conflicts, and defending choices made or proposed". ${ }^{15}$ It can be expected a priori that personal values exert strong influence on an individual's actions, behavior, and prioritization, ${ }^{16,17}$ including behavior associated with charitable giving. ${ }^{18}$ And according to Ranganathan \& Henley, ${ }^{19}$ the behavior of a donor to donate money largely depends upon cultural systems, religion, and a few personal factors. Because culture and religious beliefs are practiced among the members of a society, these trigger a particular behavior that comprises various personal, social, and psychological cues. An understanding of these personal, social, and psychological elements is pivotal to devise marketing plans that ultimately motivate donors to donate generously. ${ }^{20,21}$

This section discusses the key findings from the research with a focus on identified patterns and themes from the research and key quotes and examples where relevant; the findings related to the giving characteristics, which relate to responsible khalifa, Humble (Tawadhuk), considerate/civility and Altruisms influences in their Waqf giving behaviors.

\section{Individual interview}

Throughout this section code names will be used to identify the eight-participants. The code names are as below: Table 1

Table I Code names for Participants

\begin{tabular}{llll}
\hline Participant & \multicolumn{3}{l}{ Code names } \\
\hline Participant I & P & I.I & (Professor / donor) \\
Participant 2 & P & I.2 & (Professor / donor) \\
Participant 3 & P & I.3 & (Professor/ Researcher in policy) \\
Participant 4 & P & I.4 & (Professor / Researcher) \\
Participant 5 & P & I.5 & (Professor / donor) \\
Participant 6 & D & I.I & (Donor) \\
Participant 7 & D & I.2 & (Donor) \\
Participant 8 & H & I.I & (Awqaf Holding) \\
\hline
\end{tabular}

\section{Profile of participants}

Eight-Participants were involved in this study. A brief description of the participants is provided below: Table 2 
Table 2 Profile of Participants

\begin{tabular}{|c|c|c|c|}
\hline $\begin{array}{l}\text { Code } \\
\text { name }\end{array}$ & Present status & Responsibilities & Present status \\
\hline P I.I & $\begin{array}{l}\text { Dean of Centre } \\
\text { and lecturer }\end{array}$ & $\begin{array}{l}\text { Government } \\
\text { Policies } \\
\text { (Academics) }\end{array}$ & $\begin{array}{l}\text { Dean of Centre for Advanced Studies on Islam, Science, and Civilization } \\
\text { (CASIS), he served ISTAC as Research Fellow, then Senior Research Fellow. } \\
\text { He was Associate Professor and Curator of ISTAC Library from 2002-2003 } \\
\text { and was awarded the British Chevening Fellowship (2003-2004). }\end{array}$ \\
\hline P 1.2 & $\begin{array}{l}\text { Lecturing, } \\
\text { Publishing, \& } \\
\text { Research writing }\end{array}$ & $\begin{array}{l}\text { Government } \\
\text { Policies } \\
\text { (Academics) }\end{array}$ & $\begin{array}{l}\text { The founder of Centre for Advanced Studies on Islam, Science and } \\
\text { Civilization (CASIS), University Technology Malaysia. From } 2008 \text { to February } \\
201 \text { I he served as Principal Research Fellow at the Institute of the Malay } \\
\text { World and Civilization (ATMA), University Kebangsaan Malaysia. }\end{array}$ \\
\hline P I.3 & $\begin{array}{l}\text { Dean of School } \\
\text { and lecturer }\end{array}$ & $\begin{array}{l}\text { Government } \\
\text { Policies (Academics) }\end{array}$ & $\begin{array}{l}\text { Dean of STI Policy School, he is a leader and professional in the field of } \\
\text { science, technology, and innovation policy. }\end{array}$ \\
\hline P I.4 & Lecturer & $\begin{array}{l}\text { Government } \\
\text { Policies (Academics) }\end{array}$ & $\begin{array}{l}\text { Head of Department, Dept. of Geomatic Engineering, Chairman, } \\
\text { Smart Partnership Committee, Faculty of Geoinformation Science and } \\
\text { Engineering, UTM, 200I-2005. }\end{array}$ \\
\hline P 1.5 & Deputy VC & $\begin{array}{l}\text { Government } \\
\text { Policies (Academics) }\end{array}$ & Deputy Vice-Chancellor (Student Affairs) \\
\hline D I.I & Researcher & Welfares & Former First Director, Strategic Planning, IDB Group/ Head, IDB \\
\hline D 1.2 & Researcher & Welfares & $\begin{array}{l}\text { Board Member, Malaysian Industrial Development Authority (MIDA), } \\
\text { Member, SIRIM Technical Committee for ISO I } 4000 \text { Environmental } \\
\text { Labeling (TC3), Hon. Executive Director, Business Council for } \\
\text { Sustainable Development, Malaysia }\end{array}$ \\
\hline H I.I & Director & unity & $\begin{array}{l}\text { Chairman and Pro-Chancellor of KPJ Healthcare University College } \\
\text { (KPJUC) since 20II, Director and President Commissioner PT Khidmat } \\
\text { Perawatan Jasa Medika, 20I6-Present Independent and Non Executive } \\
\text { Director, and now OSK Holdings Berhad Chairman AWQAF Holding } \\
\text { Bhd }\end{array}$ \\
\hline
\end{tabular}

\section{Job responsibilities of the participants}

Since these participants are knowledgeable in Islamic giving behavior, naturally they are confident in their input (table 2/ Participants' Profile). Their current position is bound to government policies (academic), welfare and community services.

\section{Factors leads to giving behaviors givers' characteristics}

\section{The Trust (Amanah) given to man as a responsible Vicegerents (khalifa)}

Man was created to perform crucial and creative duties on earth as Khalifatullah. The Qur'an clearly illustrates the mission of man's creation as the most superior and worthy among all creatures, and one assigned to be a Khalifatullah on earth, which was conferred upon the Prophet Adam (pbuh). One of the definitions of the word khalifah is "a successor and vicegerent." 22 According to Mawdudi ${ }^{23}$ "Khalifah or vicegerent is one who exercises the authority delegated to him by his principal and does so in the capacity of his deputy and agent... A vicegerent is not entitled to do what he pleases, but is obliged to carry out the will of his master." In order to be a vicegerent, man should adopt the belief in Allah, worship Him and follow the practices of the Prophet and perform good deeds, as attested in the holy Qur'an. Nevertheless, man should acknowledge that Allah is most Powerful and he has no absolute power but only to hold the amanah that has been given to him.
As khalifatullah, man is given the amanah (trust), which the other creatures refused to accept because they were unable to bear its heavy responsibility (The Qur'an 33:72).

Indeed, we offered the Trust to the heavens and the earth and the mountains, and they declined to bear it and feared it; but man [undertook to] bear it. Indeed, he was unjust and ignorant. (33:72)

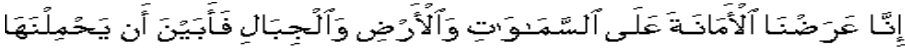

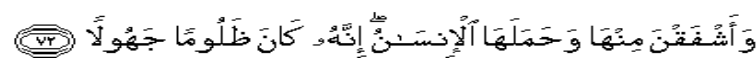

In accordance with his noble characteristics, man has the potential to fulfill this amanah in different way. One of the ways is through giving the worldly things to our brother and sister in Islam. As we are responsible in the establishment of social solidarity in accordance with the words of the Prophet (pbuh): "the connection between a Muslim and another Muslim is like one building in it's tightens; they are bound together". Thus, the individual is responsible for the society in which he lives, because he is a part of that society, and the part is inseparable from the whole. The highest goal in Islam is the happiness of all before the happiness of the part and the happiness of the community before the happiness of the individual. Islam does not recognize the happiness that based on the misery of others, and on this basis, the scholars agreed that it is obligatory for the riches to support their needy relative.

At this point, respondents highlights the trust and amanah that is given to a man as a responsible Khalifa; Quotations from some of the respondents are as follows: 
"God divided wealth to all mankind unequally; some get more than the others, thus the poor will get their portion from the rich's money through Zakat, Sadagah (charity), and Waqf in a way that Muslim as a responsible person can achieves the balance in society" (Respondent H 1.1).

"You also need to understand how waqf become the total underpinning of Islamic economy and what Islam is all about.... First the role of Islam is us (you and me) as a khalifa...Man is khalifa and abdullah (as a man, you are so given that right to perform the justice...)" (Respondent D 1.1).

"This come through man's realization and understanding of sustenance that Allah give it to him. When he/she has the access to Allah's rizkq, one will feel obliged and responsible to wisely use it in the way that pleases Allah" (Respondent P 1.1).

"Character building in our children such as responsibility and leadership will lead them to be a responsible "Khalifa", that make them use the money or the worldly things in a meaningful way to get Allah's blessing (redha)" (Respondent P 1.4).

"As a result, man harnesses the potential of others, by leading them to do good deed and/or encourage and educate them to do good action" (Respondent H 1.1).

\section{Participants responsibilities}

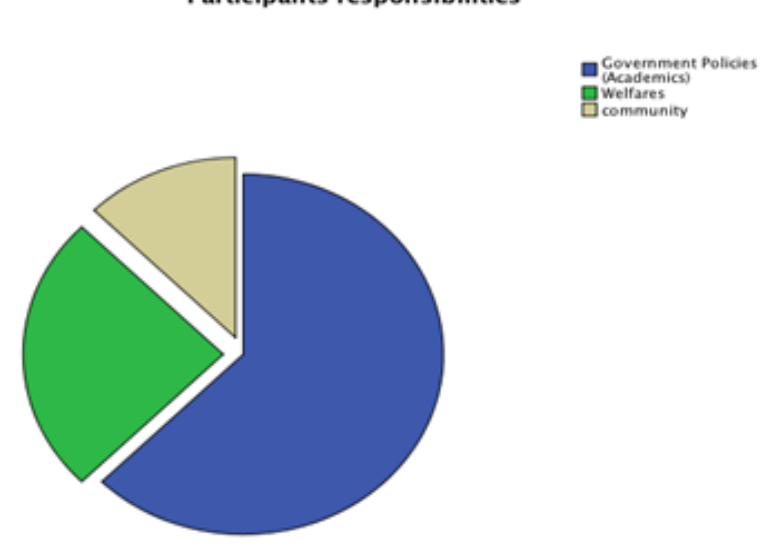

Figure I Participant responsibilities.

\section{A Kind, Charitable, Generous \& Giving Character}
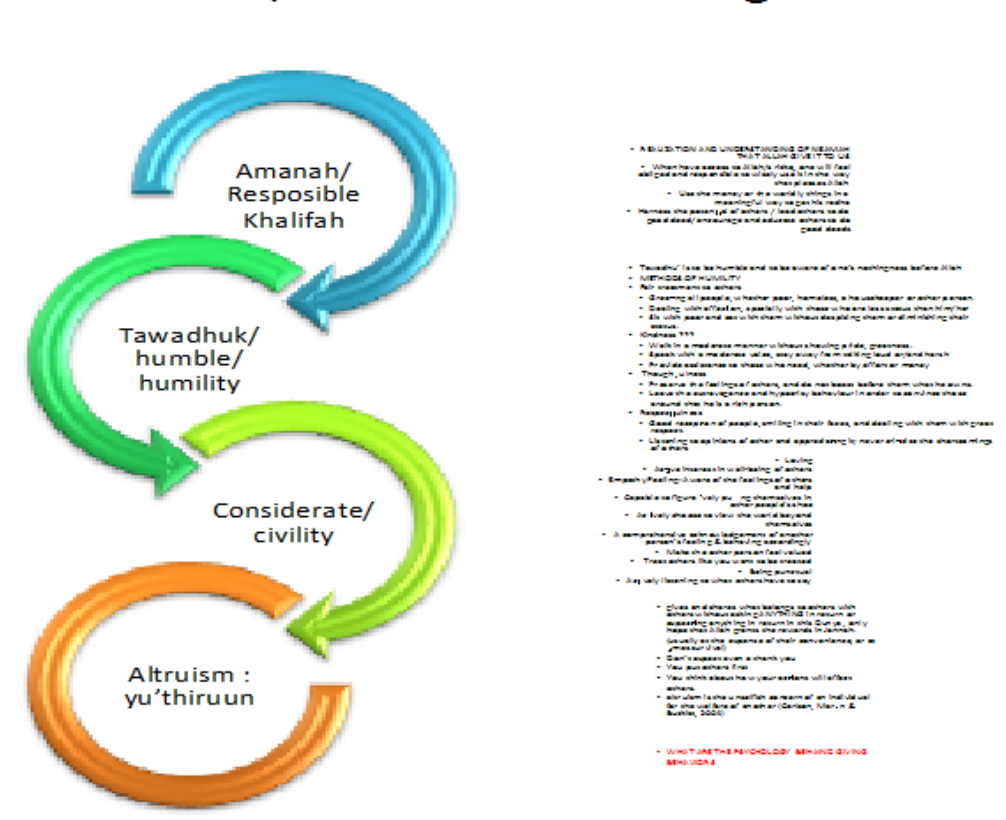

Mahdzir, A. M. \& Baqutayan, S.

Figure 2 A Kind, Charitable, Generous \& Giving character.

\section{Being humble and having the humility character (Tawadhu)}

Tawadhu' is an Islamic word refer to the way Muslim put oneself in the right position; literally means Humble. To be humble man need to be aware of one's nothingness before Allah. The methods of humility in one hand can be seen through fair treatment to others, greeting all people, whether poor, homeless, a housekeeper, or other person. On the other hand, it is dealing with affection, siting with poor and eating with them without despising them or diminishing their status. Kindness through walking in a moderate manner without showing pride, speak with a moderate voice, stay away from talking 
loud or/and harsh, provide assistance to those who need, whether by effort or money is the indication of being humble that always being encouraged by all religions. According to Shirazi, ${ }^{24}$ a humble person will not mind sitting behind everyone in a gathering. He will be the one to initiate salutations. He will give up arguments and squabbles even if he is in the right. He will not like to be praised for his piety. And Iyad ibn Himar reported: The Messenger of Allah, peace and blessings be upon him, said: Verily, Allah has revealed to me that you must be humble towards one another, so that no one wrongs another or arrogantly boasts to another

Humility means to avoid the destructive sin of arrogance and haughtiness. Arrogance is an evil deed, in which a person praises himself instead of Allah, or he considers himself superior to others, or he rejects the truth because it comes from a person he considers lesser than himself. Indeed, thoughtfulness through preserving the feelings of others, and do not boast before them what he owns, leaving the extravagance and hypocrisy behaviors in order to convince those around that he is a rich person are the best in Islam. Respectfulness and good reception of people, smiling in their faces, and dealing with them with great respect are the means for best Islamic behavior (good Akhlaq). In addition to that listening to opinions of other and appreciating it; never criticize the shortcomings of others are also important. In addition to that, giving charity with humility as Abu Hurairah (R.A.) reported Allah's Messenger (PBUH) as saying: "Charity does not in any way decrease the wealth and the servant who forgives, Allah adds to his respect; and the one who shows humility, Allah elevates him in the estimation (of the people)" (Muslim Vol. 4, Hadith 6264). Therefore, it is good for the rich to show humility before the poor to seek reward from Allah, but better than that is the overconfidence of the poor towards the rich with trust in Allah. ${ }^{24}$

At this point, respondents highlights the important of humble in giving characters; Quotations from some of the respondents are as follows:

"Humility, modesty, and forbearance are virtues that are essential for Muslims and Allah (SWT) has revealed that we should be humble towards one another and we should not boast to one another... ... Rasulullah was a perfect model of modesty and humbleness" (Respondent P 1.1)

Being Humble is very important, but there are misunderstanding of the term tawaduk in Malay culture... one is toward God and the other is toward other human being... but in today world people are getting greedy which was not the character of Muslim before... so when people become greedy, they undermine others, they do not give, they don't not share and so on. ...... . Humility is why and what are you humble with ... humility is psychosocial behavior, we need to give to others, as it's from self to others.... (Respondent D 1.1)

\section{Considerate/civility}

Loving comes when the person have active interest in the wellbeing of others, that is shown through the feeling of empathy toward others, thus, this can make man be aware of others feeling. Simply put, empathy is the ability to step into someone else's shoes, be aware of their feelings, and understand their needs. Additionally, treating others like the way you want to be treated, actively listening to what they are saying, deep respect for them, and showing the sense of caring are the psychology of man as being human. According to Swetlishoff, ${ }^{25}$ charity is the practice of benevolent caring and giving, of being considerate of others and showing compassion for their current state of being. It is also learning about the importance of empathy within self in relation to others, and how this quality of love expressed brings profound joy to both the giver and the receiver. Charity is doing acts out of love without thought for something in return and is beyond mere kindness; it is the pure joy of giving, which includes much more than material things. This giving from the heart can have many faces, such as sharing a warm smile with a stranger, an encouraging hug to a friend or family member, or kind and thoughtful word of appreciation. When one expresses the loving quality of charity, it means they have loving tolerance, compassion and patient empathy for the perceived failings or errors of others. All of this is done not out of a sense of duty or responsibility but rather out of the abundance of warmth and love that one feels welling up inside them. The more charity one gives out to others, the more flows back in. This is the joy of love in action, the outward manifestation of charity where one kind action leads to another. A single act of kindness from one person throws out kindness in a radiating circle, and the action taken touches more people than an individual realizes. Therefore, the Prophet Muhammad, may the mercy and blessings of God be upon him, said in a narration, known to perhaps every devout Muslim:

"None of you truly believes until he loves for his brother what he loves for himself." (Saheeh Al-Bukhari)

Respondents highlights their view on considerate/civility as follows:

"Loving our Muslim brothers and sisters will motivate us to participate in waqf" (Minister of education)

"We need to be a person who always sympathize with others and show the love toward them; then we will participate in waqf" (Respondent P 1.5)

"Loving includes giving, caring and trusting on the person whom you love.... the love is manifested through Victorian presentation of that... we give in term of action and not says... The love is how you interpret it in your own life... the way you live, they way you interact with people and the way you design your own life can interpret your loves toward others" (Respondent D 1.1).

\section{Altruism (Etharah/yu'thiruun)}

Giving and sharing what do you have with others without asking anything in return or expecting anything in return in this life, only hope that Allah grants the rewards in Jannah. As a man who hold the altruism behavior he/she don't expect even a word of thanks from others as he always put others first, thinking about how his/her actions will affect others. Altruism is the unselfish concern of an individual for the welfare of another. ${ }^{26}$

Altruism, selfless acts done for another's benefit in spite of oneself, is a humanitarian endeavor praised by all societies. ${ }^{27}$ Practically every nation on earth has stories of great kings, brave warriors and noble men and women who sacrificed their material possessions, status, or even themselves for some or other common good. Yet, it is without any reservation or hesitation whatsoever that we can point to the religion of Islam for the most perfect, sincere, and comprehensive expression of altruism (Eethaar in Islamic terminology). The Prophet Muhammad (PBUH) said: None of you truly believes until he loves for his brother what he loves for himself." (Saheeh Al-Bukhari) 
And with that, altruism instantly becomes a condition of true faith in God, Most High. This act of faith was demonstrated so many times throughout the history of Islam, from Muhammad's commission as a prophet up until our present times, that to recall even a fraction of the authentic narrations that have reached us would barely touch the surface. However, for the purpose of this discussion, we will do just that.

Altruism in Islam is different from other religions because every religion requires you to be kind, but Islam goes down to the minutest details. For example, Muslims are supposed to know their neighbors well enough to be able to help them out with their problems. Finally, when we look at the precedent set by actual societies, we find that among the happiest of societies was the first Muslim society. Those Muslims were the reflection of Islamic doctrines in the Quran and Sunnah; they were helping each other, neither for money, nor for fame but for the sake of Allah. "A believer is like a brick for another believer, the one supporting the other," said the Prophet Muhammad (saws) (Bukhari).

\section{Respondents highlights their view on altruism as follows:}

“... Altruism is non-scenes phenomena (if you want to see, you cannot see, because it cannot be seen), so it's a direction of doing goodness and good things. So altruism is not in giving alone, the haleness (wholeness) of altruism is that the components must be perfect. ... The altruism is that you are great because of character and conduct and not because you are acting as a giver,........... the poor can be better than the rich, if he gives one dollar which is too big and a rich who never feel shame to give same amount as what the poor give (the parity of justice). So altruism is character and conduct but not act..." (Respondent D 1.1).

\section{Conclusion}

The diverse features and qualities in man's nature, as the foregoing discussion indicates that man by nature has a great potential to be good. This is because Allah has fashioned him perfectly, and breathed His soul into him; this makes him ready to perform goodness and obtain good conduct and behavior. He has appointed him as Khalifahtullah and granted him superiority over other creatures. He has equipped him with intellect, senses, and great feelings toward other creatures, such as loving, caring, sympathizing, consideration, as well as empathizing, and granted him all sorts of blessings. However, all these features, characters, and qualities of man are still subject to change because of different reasons. Therefore, in order to intensify the character of being great man, we should understand the psychology of being good, by considering one noble character as giving charity. Realizing the importance of giving as a mechanism to study the behavior of Muslim, it is not clear what is the psychology of giving and how people are motivated to contribute physically, emotionally, and financially. The purpose of the study is to determine factors motivating the giving behaviors; therefore, this research began with an overview of the psychology that influences giving and/or creating waqf among Muslim. It defined the concept of "giving" in an individual and explored the four factors that have been noted to make a difference in creating Waqf. The four factors were Amana given to the man as a responsible khalifa, Humble/Humility (Tawadhuk), considerate/civility elements, and Altruisms. The study concluded that the four-factor model was an important construct to predict givers behavior, which are crucial predictors. This study also gives practical contributions to the waqf researchers by identifying factors that can influence the Muslim to create waqf. As the research on waqf giving behavior are still lacking, this study is trying to solve the problem by determining the factors influencing waqf-giving behavior. There is empirical evidence provided, as the paper used qualitative method to measure the items from different perspectives. The theoretical implication for this study is the proposed research model on giving behavior. Researchers can applied this model for further research on waqf related issues.

\section{Acknowledgements}

This paper is an output of a project funded by Ministry of Education (Cost Center No. R.K130000.7839.4F914). Therefore, I would like to express my special thanks of gratitude to The Ministry of Education as well as Universiti Teknologi Malaysia (UTM) who gave me this golden opportunity to do this wonderful project under the (Fundamental research grants). I came to know about so many new things that helped me in doing a lot of publications, I am really thankful to them. My sincere thank also to all my colleagues who kindly provided valuable and helpful comments for this paper.

\section{Conflicts of interest}

The author declares no conflicts of interest.

\section{References}

1. Drezner ND, Huehls F. Fundraising and Institutional Advancement: Theory, Practice, and New Paradigms. New York: Routledge. 2015.

2. Charities Aid Foundation. Why we give. 2014.

3. Unite For Sight. The Motivation for Giving. 2015.

4. ESRC/National Council for Voluntary Organisations (NCVO). Why do people give to charity-and why don't others? How do we encourage more giving? ESRC Seminar Series - Mapping the public policy landscape. 2005

5. Sargeant A, Lee S. Trust and relationship commitment in the United Kingdom voluntary sector: determinants of donor behavior. Psychology and Marketing. 2004;21(8):613-635.

6. Radley A, Kennedy M. Charitable giving by individuals: a study of attitudes and practice. Human Relations. 1995;48(6):685-709.

7. Ramayah T, Yousuf M, Norzalila J, et al. Applying the theory of planned behavior (TPB) to predict internet tax filing intentions. International Journal of Management. 2009;26(2):272-284.

8. Anik L, Aknin LB, Norton MI, et al. Feeling Good about Giving: The Benefits (and Costs) of Self-interested Charitable Behavior. In: DM Oppenheimer, CY Olivola, editors. The Science of Giving: Experimental Approaches to the Study of Charity. Psychology Press. 2010.

9. Vesterlund L. Why do people give. The nonprofit sector: A research handbook, 2, 2006:168-190.

10. David Crabtree. The importance of History. Gutenberg College. 2001.

11. Zagefka H, James T. The Psychology of Charitable Donations to Disaster Victims and Beyond. Social Issues and Policy Review. 2015;9(1):155192.

12. McShane, Glinow. Organizational behavior, emerging knowledge and practice for real world. (5th ed.), McGraw. Hill, International Edition. Singapore. 2010.

13. Explorable.com. Quantitative and Qualitative Research. 2009. 
14. Francia PL, Green JC, Herrnson PS, et al. Limousine liberals and corporate conservatives: the financial constituencies of the democratic and republican parties. Social Science Quarterly. 2005;86(4):761-778.

15. Rokeach M. Understanding Human Values. Free Press: New York. 1979.

16. Fall L. An exploratory study of the relationship between human values and information sources within a tourism framework. Journal of Hospitality and Leisure Marketing. 2000;7(1):3-28.

17. Kahle L, Rose G, Shoham A. Findings of LoV throughout the world and other evidence of cross-national consumer psychographics. Journal of Euromarketing. 2000;8(1/2):1-13.

18. Bennett R. Factors underlying the inclination to donate to particular types of charity. International Journal of Nonprofit and Voluntary Sector Marketing. 2003;8(1):12-29.

19. Ranganathan SK, Henley WH. Determinants of charitable donation intentions: a structural equation model. International Journal of Nonprofit and Voluntary Sector Marketing. 2008;13(1):1-11.

20. Knowles SR, Hyde MK, White KM. Predictors of young People's charitable intentions to donate money: an extended theory of planned behavior perspective. Journal of Applied Social Psychology. 2012;42 (9):2096-2110
21. Warburton J, Terry DJ. Volunteer decision making by older people: A test of a revised theory of planned behavior. Basic and Applied Social Psychology. 2000;22:245-257.

22. Edward William Lane. Arabic-English Lexicon. Cambridge. Volume 1, 1984. p. 797.

23. Maududi, Sayyid Abul Ada. Towards Understanding the Qur'an. Volume 1. In: Zafar Ishaq Ansari. Leicester. 1988. p. 59-60.

24. Shirazi ASAHD. Greater Sins. Volume 3, Islamic Study Circle, Mumbai, India. 2004

25. Swetlishoff M. Charity is an act of Creation. 2015.

26. Carlson NR, Martin GN, Buskist W. Psychology. 2nd ed, Essex: Pearson Publishing. 2004.

27. Mahdi A. The perfect altruism of the earliest Muslim society, a unique example for later generations. 2006. 